This item was submitted to Loughborough's Research Repository by the author.

Items in Figshare are protected by copyright, with all rights reserved, unless otherwise indicated.

\title{
Soldner fur den Anschluss: die osterreichische Legion, 1933-1938, by Hans
} Schafranek

PLEASE CITE THE PUBLISHED VERSION

http://dx.doi.org/10.1093/ehr/ceu066

PUBLISHER

(c) Oxford University Press

VERSION

SMUR (Submitted Manuscript Under Review)

LICENCE

CC BY-NC-ND 4.0

\section{REPOSITORY RECORD}

Knight, Robert. 2019. "Soldner Fur Den Anschluss: Die Osterreichische Legion, 1933-1938, by Hans Schafranek”. figshare. https://hdl.handle.net/2134/15535. 
This item was submitted to Loughborough's Institutional Repository (https://dspace.lboro.ac.uk/) by the author and is made available under the following Creative Commons Licence conditions.

\section{creative
commons}

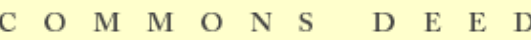

Attribution-NonCommercial-NoDerivs 2.5

You are free:

- to copy, distribute, display, and perform the work

Under the following conditions:

Attribution. You must attribute the work in the manner specified b the author or licensor.

Noncommercial. You may not use this work for commercial purposes.

No Derivative Works. You may not alter, transform, or build upon this work.

- For any reuse or distribution, you must make clear to others the license terms of this work.

- Any of these conditions can be waived if you get permission from the copyright holder.

Your fair use and other rights are in no way affected by the above.

This is a human-readable summary of the Leqal Code (the full license).

\section{Disclaimer 만}

For the full text of this licence, please go to: http://creativecommons.org/licenses/by-nc-nd/2.5/ 
Söldner für den Anschluss: die österreichische Legion 1933-1938, by Hans Schafranek (Vienna: Czernin Verlag, 2011; pp. 496)

Hans Schafranek's book examines, in depth and expertly, the careers of nearly 15,000 Nazi activists (nearly all of them SA members), who fled to Germany after the Austrian Chancellor Engelbert Dollfuss banned the Nazi party in June 1933. The previous year the Nazis had achieved major electoral breakthrough in Austria, gaining up to $20 \%$ of the vote in regional elections, and enthused by Hitler's takeover, they started a campaign of bombings and assassinations to topple the Austrian government. By the time of the ban membership had reached 68,000 . Those who then sought refuge were placed in camps close to the border, placed under the command of Hermann Reschny (Führer der SAGruppe Österreich) and given the grandiose title of 'Austrian Legion'. From the camp they made periodic forays into Austria, where they planted bombs in Jewish businesses or on railway bridges, and raided isolated customs posts or Gendarmerie posts. These messy and distinctly unheroic activities (including one involving Jörg Haider's father Robert) cost several lives but failed to topple the 'austro-fascist' regime. Following the fiasco of the 1934 'July putsch' and Hitler's decision to follow an 'evolutionary path' towards the Anschluss, these activities were reduced but not stopped. Although numbers gradually dropped the transformation into the incocuous-sounding Hilfswerk Nordwest was largely fictional.

Schafranek (in collaboration with Andrea Hurton) has trawled through a huge quantity of archival material to give us the most comprehensive picture yet on the Legion's activities and attitudes; personnel files of the SA, police and court records, the German (Bavarian) and Austrian foreign and interior ministry files, form the backbone of his research. The resulting picture of the 'legionaries' deepens and extends our knowledge of institutional infighting (e.g. with the illegal Nazi organisation or the SS) and gives us a more complex and solid understanding of their biographical and motivational background. Schafranek's analysis of social background of 5,263 individuals suggest that apprentices and unskilled workers (Hilfsarbeiter) were overrepresented (17\%) 
(67). The overall impression of the camps, is of a teeming anthill of seething resentment and pent-up frustration, with the high-flown rhetoric of heroism and sacrifice all too swiftly lapsing into pathos and self-pity. Violence of one kind or another was never far from the surface, as an outlet for the boredom of camp life and the uncertainty about the future. On the receiving end were no longer communists or socialists, as in earlier SA street violence, but Bavarian villagers taking part in dances or defending their priests against allegations of paedophilia.

One of the main themes emerging from Schafranek's account is role of contingency and biographical accident. As well as unemployment, alcohol, debt or blackmail could act as triggers. The effect downgrades somewhat the role of ideology, Schafranek describes two key elements in their 'ideological knapsack' as a 'hatred of the Dollfuss regime' and a 'boundless illusions about Nazi "reconstruction project"' (19). Naturally anti-Semitism was also a core belief for most though one remarkable encounter described here shows that it might also be set aside: Günther Mark von Traisenthal_tried to pick up Gertrud Feuchtwanger (the writer's sister) in the Munich cafe (Fürstenhof) (p. 252). Schafranek records her withering response to the invitation to join him to his hotel room: she explained that she was 'shock, horror' not a Nazi but 'only a Jewess' and asked him to imagine Herr Streicher would say 'if he found both of us together in your room, which you've invited me into." Von Traisenthal was undeterred.

The prominence of this kind of low-life incident and the relatively minor role of ideology, is also, as Schafranek readily concedes (206), partly because more information is available about those who became 'cases' and as a result left a documentary trail for the historian to pursue. Some of these led to police investigation and trial in Austria (in a few cases in the post-war 'People's Court') others to internal SA disciplinary proceedings. Schafranek compares the latter to Stalinist style confessions (inquisition rituals 279). One of several bizarre moments came after the indignant accusation by one Hans Kutschera, charged among other things with 'desertion', that he had been beaten up by his interrogaters. His interrogator conceded that 'we weren't gentle with him' yet 'he hadn't been beaten' "wir gingen nicht zart mit ihm um er bekam wohl 
auch ab und zu einen Stoss, ich entsinne mich auch, dass ich ihn einmal beim Genick packte und ihn über den Stuhl legte. Aber auch dabei ist Kutschera nicht geschlagen worden' (284).

The 1936 July Agreement between Berlin and Vienna meant that future German- Austrian differences were to be treated as internal matter between two German states. It also brought an amnesty for 18,000 inviduals. For those sitting in Austrian prisons, like Franz Ammerer it meant the chance to reinvent themselves as heroic victims although he also risked being punished for having acted for opportunistic motives ('aus haesslichem Eeignnuetz 281). When it came, the Anschluss proved a disappointment. The legion was allowed one triumphal parade, given a supervisory role in the stage-managed Plebiscite of April 1938 and then dissolved. In the headlong rush for posts and Jewish property it members were only one group among many and, Schafranek argues, had less clout from most of the others. Some of the resulting frustration was chanelled into antisemitic actions, and the repeated and insistent demand for redress ('Wiedergutmachung') for the years they had sacrificed to the cause.

Robert Knight

Loughborough University 